\title{
The Estimation of Beef Carcass Traits using Computer Image Analysis for Body Measurement in Japanese Black Steers
}

\author{
Keigo Kuchida*, Toshihiro Yamagishi, Hisato TaKEDA** \\ and Kuniji YAMAKI \\ Faculty of Agriculture, University of Tohoku, \\ Aoba-ku, Sendai-shi 981 \\ ${ }^{* *}$ National Institute of Agro-Biological Resources, \\ Tsukuba-shi 305
}

(Recived January 18, 1993)

\begin{abstract}
Three-dimension images (rear and dorsal view) of 40 Japanese Black steers were photographed by video camera, and inputted into a computer memory. The live body contour lines were detected by a computer program described with $C$ language. In this study, the contour lines of dorsal and rear images are numerically expressed using quadratic regression coefficients (defined as dorsal and rear parabola scores, respectively). Similarly, the ratios between width and height of the body in dorsal and rear images are used (defined as dorsal and rear width scores, respectively). Twelve live body measurements, thirty-three carcass traits and subcutaneous fat thickness via the ultrasound method were also measured. The images analysis traits and live body measurements were used for the prediction of carcass traits by multiple regression. The $\mathrm{R}^{2}$-values of the equations for estimating beef marbling and beef color standard numbers were improved by putting the image analysis traits into multiple regression equations. Upper and rear parabola scores had a positive influence on beef marbling standard numbers. Similarly, the upper parabola score, dorsal width score and rear parabola score significantly affected beef color standard numbers. Their partial regression coefficients were negative in each case. Slight improvements for predicting meat luster and meat texture were detected by adopting these image analysis traits.
\end{abstract}

Anim. Sci. Technol. (Jpn.) 65 (5) : 401-406, 1994

Key words : image analysis, body measurement, Japanese Black, prediction of carcass traits

It has been reported that body measurement traits in live cattle are useful for predicting quantitative and qualitative carcass traits ${ }^{4)}$. YAMAZAKI et al. ${ }^{10)}$ developed a three dimensional measurement method for shape eveluation of live cattle using body contour lines. They found this method was useful for estimating the degree of fattening as the rib and hip width would become wider with increased fattening.
KUCHIDA et al.$^{5,5)}$ reported on an evaluation method for beef meat quality via computer image analysis, and developed a method for measuring the shape of the intramuscular fat depot in the rib-eye muscle. From their results, it was easy for the computer to treat curvilinear outlines with the image analysis method.

The purpose of this study was to develop a method for measuring the rump shape of live

Present address : * Sendai Municipal Institute of Public Health, Wakabayashi-ku, Sendai-shi 983 
cattle by computer image analysis, and to investigate the possibility of using the image analysis method for predicting quantitative and qualitative carcass traits.

\section{Materials and Methods}

Live body and carcass traits were measured for 40 Japanese Black steers sired by 4 bulls produced in a progeny testing project at Miyagi prefecture. Live body measurements and video photographing were carried out 2 days before slaughter. Measurements on live bodies were done for body height, height at hip cross, body length, chest girth, chest depth, chest width, rump length, hip width, thurl width, pin bone length, shank circumference and body weight.

Three-dimensional images (rear and dorsal view) were taken by color video camera (Sony Co. Ltd. : CCD-V 700) as shown in Fig. 1. The video camera for the dorsal view was set at a height sufficient to take a complete image, and was remote controlled. The rear images were taken from $0.75 \mathrm{~m}$ above ground level.

The video images from both directions were input into a computer memory via an $\mathrm{A} / \mathrm{D}$ (analog/digital) converter (Digital arts Co. Ltd. : Hyper vision + ). The contour lines of the live body were almost automatically detected by computer, and the noised lines were manually corrected. A PC-9801 personal computer (NEC Co. Ltd.) was used for image analysis, and the programs were written in $\mathrm{C}$ language ${ }^{3)}$.

In this study, the contour lines for dorsal and rear images are expressed numerically using equations as shown in Fig. 2. Only dorsal view images of the hind parts of the body were

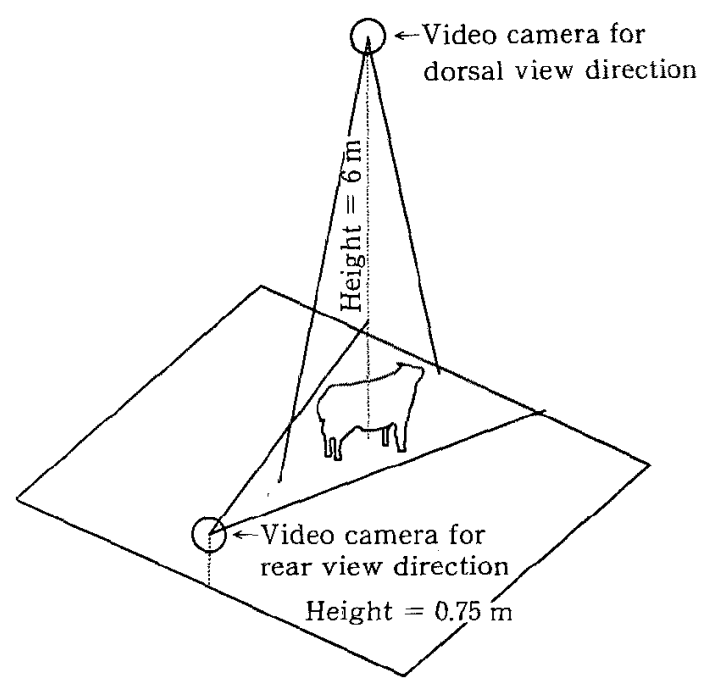

Fig. 1. Video photographing system from two directions for cattle. (a) Upper parabola and width score

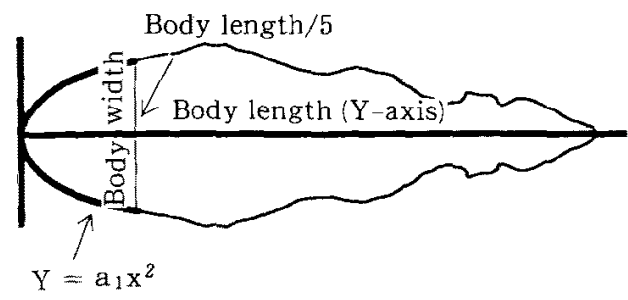

Upper parabola score : $a_{1}$

Upper width score $: \frac{\text { Body width }}{0.2 \text { Body length }}$ (b) Rear parabola and width score

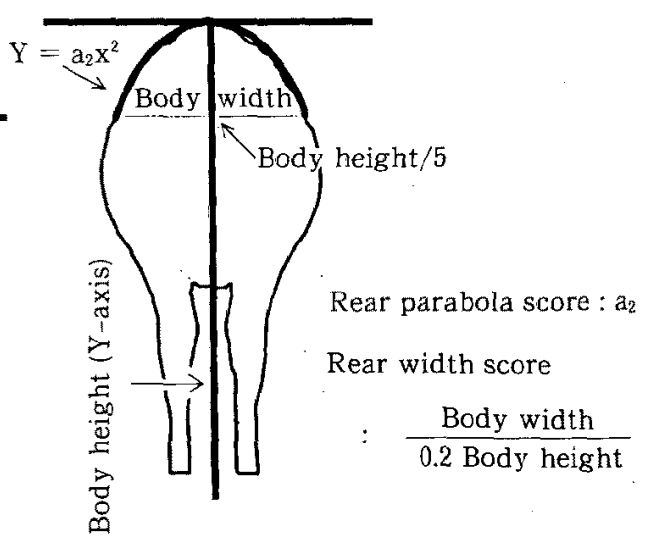

Fig. 2. Calculation method of parabola and width scores from dorsal and rear view on cattle. 
used in image analysis, because the images of other body parts fluctuated according to the standing posture or the reticuloruminal movement of cattle. The upper parabola score $a_{1}$ was the coefficient of quadratic equation $\mathrm{Y}=$ $\mathrm{a}_{1} \mathrm{X}^{2}$ and a factor affecting rump and thurl shapes. The outlines of the dorsal view of live cattle are drawn on coordinates, where the median line of the body is defined as the $\mathrm{Y}$ axis, the rectangular line to $\mathrm{Y}$ at the posterior edge of the body is the $\mathrm{X}$ axis, and the contact point is the origin. Quadratic regession analysis was applied to the curvilinear outline of the body with in the range of $1 / 5$ body length on the image from the origin. Similarly, rear parabola score $\mathrm{a}_{2}$ was calculated by setting coordinates on an image taken of the rear view of cattle as shown in Fig. 2, and analysis was done in the same way as for the dorsal view. Dorsal and rear width score are defined as shown in Fig. 2, respectively. The parabola and width scores were standardized by assuming that $1 / 5$ body length or $1 / 5$ body height equalled 1.0 , respectively.

Since ultrasound measurements are useful for evaluating the degree of fattening, we expected improved accuracy of prediction for carcass traits by including ultrasound measurement values in multiple regression equations. These measurement values were thus included in such equations with live body measurements and image analysis traits. Ultrasound measurement was performed at six points based upon the method reported by NAGAMine et al. ${ }^{8)}$ : four points beside the median line of the body and two abdominal side points in relation to those points which were selected on the left side of the body. Three ultrasound measurement values were used in this study; the summed thickness of all six points, the summed thickness of the four points beside the median line, and the summed thickness of the two abdominal points.

Carcass weight, dressing percentage, rib-eye area, rib thickness, subcutaneous fat thickess, yield score, intermuscular fat thickness and carcass length were measured as carcass quantity traits, and beef marbling standard number (BMS), beef color standard number (BCS), meat luster, firmness, texture, beef fat standard number and fat luster quality were evaluated as carcass quality traits in progeny testing.

The multiple regression analyses for prediction of carcass traits were performed with all live body measurements, image analysis traits and ultrasound measurements. Statistical analysis was done by using SAS $^{9}$.

\section{Results and Discussion}

The mean, standard deviation and skewness of image analysis traits are shown in Table 1. For parabola scores, there was no difference between upper or rear values, but the mean differed significantly between width scores ( $p$ $<0.05)$. The detailed characteristics of these scores should be investigated after collecting more data.

The relationships between parabola and width scores and body or carcass measurements are shown in Table 2. Upper parabola score correlates negatively $(p<0.05)$ with body length, cheat girth, chest depth, chest width, thurl width, body weight and carcass traits related to the degree of growth and fattening.

Table 1. Means, standard errors and skewnesses of parabola and width scores by view directions $(\mathrm{n}=40)$

\begin{tabular}{|c|c|c|c|c|}
\hline \multirow{2}{*}{ View from } & \multicolumn{2}{|c|}{ Parabora scores } & \multicolumn{2}{|c|}{ Width scores } \\
\hline & Mean $\pm S$. E. & Skewness & MeantS. E. & Skewness \\
\hline Dorsal & $0.022 \pm 0.0003^{a}$ & 0.288 & $1.35 \pm 0.009^{a}$ & 0.706 \\
\hline Rear & $0.024 \pm 0.0014^{\mathrm{a}}$ & 0.640 & 2. $10 \pm 0.023^{b}$ & -0.037 \\
\hline
\end{tabular}

$a, b:$ Means with different superscripts within same column differ significantly at $p<0,05$. 
Table 2. Correlation coefficience of parabora and width scores with body and carcass measurements for Japanese Black steers $(n=40)$

\begin{tabular}{|c|c|c|c|c|c|c|c|c|c|c|c|}
\hline & t & $\begin{array}{l}\text { Hip } \\
\text { cross }\end{array}$ & $\begin{array}{l}\text { Body } \\
\text { length }\end{array}$ & $\begin{array}{l}\text { Chest } \\
\text { girth }\end{array}$ & & & & $\begin{array}{l}\text { Hip } \\
\text { width }\end{array}$ & & $\begin{array}{l}\text { Pin }^{3} \\
\text { length }\end{array}$ & im \\
\hline Nper p.s. & 0.265 & -0.158 & $-0.465^{*}$ & $-0.432^{*}$ & $-0.399^{*}$ & -0.511 & -0.034 & -0.121 & & -0.060 & 0.191 \\
\hline Rear p.s. & 0.172 & 0.107 & -0.066 & 0.178 & 0.239 & 0.136 & 0.010 & $-0.386^{*}$ & -0.179 & -0.224 & $-0.420^{*}$ \\
\hline Upper w.s." & -0.197 & -0.286 & -0.109 & 0.197 & 0.059 & 0.126 & -0.173 & 0.010 & -0.033 & -0.181 & $-0.383^{*}$ \\
\hline \multirow[t]{2}{*}{ Rear w.s. } & -0.156 & -0.260 & -0.006 & $0.438^{*}$ & 59 & $0.341^{*}$ & 0.044 & 66 & -0.196 & -0.258 & -0.284 \\
\hline & & $\mathrm{k} 1$ & $\begin{array}{l}\mathrm{F} \\
\mathrm{th}\end{array}$ & 3 & & & $\begin{array}{l}\mathrm{Ri} \\
\text { ar }\end{array}$ & & & & \\
\hline per p.s. & & & & & & & & & & & \\
\hline Rear p.s. & -0.013 & $0.370^{*}$ & $0.411^{*}$ & 0.215 & 0.003 & 0.218 & -0.185 & 0.127 & -0.280 & 0. 1.11 & -0.094 \\
\hline Upper w.s. & 0.052 & 0.217 & 0.226 & 0.150 & 0.054 & 0.177 & -0.151 & -0.020 & -0.268 & 0.021 & 0.170 \\
\hline \multirow[t]{2}{*}{ Rear w.s. } & 0.184 & $0.433^{*}$ & $0.456^{*}$ & 0.291 & 0.225 & $0.351^{*}$ & 0.022 & $0.395^{*}$ & 0.079 & 0.103 & 0.252 \\
\hline & $\begin{array}{l}\text { Carcass } \\
\text { length }\end{array}$ & $\mathrm{BMS}^{8}$ & & $\mathrm{r}$ & 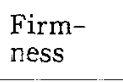 & & 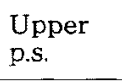 & S & 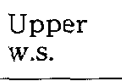 & s. & \\
\hline opper p.s. & $-0.492^{*}$ & $=0.017$ & -0.091 & -0.002 & 0.249 & 0.191 & 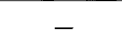 & -0.44 & & -0 & \\
\hline Rear p.s. & 0.141 & $0.374^{*}$ & -0.233 & 0.180 & 0.125 & -0.268 & $-0.444^{*}$ & - & 0.286 & $0.391^{*}$ & \\
\hline Upper w.s. & -0.134 & 0.102 & -0.265 & 0.101 & $-0.344^{*}$ & -0.209 & $-0.355^{*}$ & 0.286 & - & $0.461^{*}$ & \\
\hline Rear w.s. & -0.068 & 0.174 & -0.266 & -0.119 & -0.296 & 0.038 & $-0.393^{*}$ & $0.391^{*}$ & $0.461^{*}$ & - & \\
\hline
\end{tabular}

${ }^{*}: \mathrm{p}<0.05,{ }^{1)}$ p.s. : parabola score, ${ }^{2)}$ w.s. : width score, ${ }^{3)}$ pin length : pin bone length, ${ }^{4)}$ Fal thick $1:$ summed thickness of all six points measured by ultrasound method, ${ }^{\text {s) }}$ Fat thick 2 : summed thickness of four points beside median line, ${ }^{6}$ Fat thick 3 : summed thickness of two abdominal points, ${ }^{7}$ Inter. fat : Intermuscular fat thickness, ${ }^{8}$ BMS : beef marbling standard, ${ }^{9)}$ BCS : beef color standard, ${ }^{(0)}$ BFS : beef fat standard.

Texture and fat luster quality were same value in each steer.

These results indicate that cattle with small body size and an angular rump shape tend to demonstrate a high upper parabola score. Rear parabola scores correlated positively with fat thickness (the summed thickness of all 6 points, the summed thickness of the 4 points beside the median line) and BMS, and correlated negatively with hip width and shank circumference $(\mathrm{p}<0.05)$. The correlation coefficients of rear width score with chest girth, chest width and fat thickness (the summed thickness of all 6 points, and the summed thickness of the 4 dorsal points) were significant and positive $(\mathrm{p}<0.05)$. Therefore, parabola and width scores were interpreted as the index of fatness.

Concerning the relationship between these parabola and width scores, upper parabola scores correlated negatively with the other three scores $(p<0.05)$. Positive correlation co- efficients were recognized between rear width scores and rear or upper parabola scores.

Multiple regression analyses for 13 carcass traits were done using 15 body measurements, 2 parabola scores and 2 width scores as independent variables (shown in Table 3). When parabola and width scores were included in multiple regression equations for $\mathrm{BMS}$ and BCS estimation, greatly improved $R^{2}$-values were obtained compared with equations calculated with only live body measurements. These two carcass quality traits are especially important factors in Japanese beef grading standards. The partial $\mathrm{R}^{2}$-values of upper parabola score $(0.16)$, rear parabola score $(0.14)$, body weight $(0.07)$ and rump length $(0.04)$ were significant, and they all effectively improved $\mathrm{R}^{2}$-values in the equation for BMS estimation. Rear and upper parabola scores also positively affected BMS estimation. Similarly, partial $\mathrm{R}^{2}$ 
Table 3. $\mathrm{R}^{2}$-value and adjusted $\mathrm{R}^{2}$-value of multiple regression analysis for carcass traits by 15 body measurement traits and parabora and width scores $(n=40)$

\begin{tabular}{|c|c|c|c|c|c|}
\hline \multirow[b]{2}{*}{$\begin{array}{c}\text { Dependent } \\
\text { variables }\end{array}$} & \multicolumn{2}{|c|}{ Independent variables } & \multirow[b]{2}{*}{$\begin{array}{c}\text { Dependent } \\
\text { variables }\end{array}$} & \multicolumn{2}{|c|}{ Independent variables } \\
\hline & $\begin{array}{l}\text { Body } \\
\text { measurements }\end{array}$ & $\begin{array}{l}\text { P.S. and W.S. } \\
\text { +body } \\
\text { measurements }\end{array}$ & & $\begin{array}{l}\text { Bocy } \\
\text { measurements }\end{array}$ & $\begin{array}{l}\text { P.S. and W.S. } \\
+ \text { body } \\
\text { measurements }\end{array}$ \\
\hline $\begin{array}{l}\text { Carcass } \\
\text { weight }\end{array}$ & $\begin{array}{l}0.924^{* * c} \\
0.917^{\circ}(3)^{e}\end{array}$ & $\begin{array}{l}0.926^{* *} \\
0.919 \text { (3) }\end{array}$ & $\begin{array}{l}\text { Body } \\
\text { length }\end{array}$ & $\begin{array}{l}0.807^{* *} \\
0.778 \text { (5) }\end{array}$ & $\begin{array}{l}0.807^{* *} \\
0.778(5)\end{array}$ \\
\hline $\begin{array}{l}\text { Dressing } \\
\text { percentage }\end{array}$ & $\begin{array}{l}0.307^{* *} \\
0.249 \text { (3) }\end{array}$ & $\begin{array}{l}0.370^{* *} \\
0.298 \text { (4) }\end{array}$ & BMS & $\begin{array}{l}0.114^{*} \\
0.090(1)\end{array}$ & $\begin{array}{l}0.407^{* *} \\
0.339 \text { (4) }\end{array}$ \\
\hline $\begin{array}{l}\text { Rib-eye } \\
\text { area }\end{array}$ & $\begin{array}{l}0.472^{* *} \\
0.428 \text { (3) }\end{array}$ & $\begin{array}{l}0.477^{* *} \\
0.433(3)\end{array}$ & $\mathrm{BCS}$ & $\begin{array}{l}0.278^{*} \\
0.196 \text { (4) }\end{array}$ & $\begin{array}{l}0.499^{* *} \\
0.389(7)\end{array}$ \\
\hline $\begin{array}{l}\text { Rib } \\
\text { thickness }\end{array}$ & $\begin{array}{l}0.590^{* *} \\
0.556 \text { (3) }\end{array}$ & $\begin{array}{l}0.590^{* *} \\
0.556 \text { (3) }\end{array}$ & $\begin{array}{l}\text { Meat } \\
\text { luster }\end{array}$ & $\begin{array}{l}0.257^{*} \\
0.195 \text { (3) }\end{array}$ & $\begin{array}{l}0.314^{* *} \\
0.256 \text { (3) }\end{array}$ \\
\hline $\begin{array}{l}\text { Subcutaneous } \\
\text { fat thickness }\end{array}$ & $\begin{array}{l}0.468^{* *} \\
0.390 \text { (5) }\end{array}$ & $\begin{array}{l}0.514^{* *} \\
0.425 \text { (6) }\end{array}$ & $\begin{array}{l}\text { Meat } \\
\text { texture }\end{array}$ & $\begin{array}{l}0.490^{* *} \\
0.415 \text { (5) }\end{array}$ & $\begin{array}{l}0.555^{* *} \\
0.474 \text { (6) }\end{array}$ \\
\hline $\begin{array}{l}\text { Yield } \\
\text { score }\end{array}$ & $\begin{array}{l}0.080 \\
0.056(1)\end{array}$ & $\begin{array}{l}0.103 \\
0.055(2)\end{array}$ & BFS & $\begin{array}{l}0.297^{*} \\
0.216 \text { (4) }\end{array}$ & $\begin{array}{l}0.296^{*} \\
0.216(4)\end{array}$ \\
\hline $\begin{array}{l}\text { Intermusclar } \\
\text { fat thickness }\end{array}$ & $\begin{array}{l}0.278^{* *} \\
0.259(1)\end{array}$ & $\begin{array}{l}0.278^{* *} \\
0.259(1)\end{array}$ & & & \\
\hline
\end{tabular}

${ }^{a}$ : Parabora score, ${ }^{b}:$ width score, ${ }^{c}: R^{2}-$ value, ${ }^{d}$ : adjusted $R^{2}$-value, ${ }^{e}:$ Each value in parentheses is the number of selected independent value in multiple regression analysis.

${ }^{*}: p<0.05,{ }^{* *} p<0.01$.

-values for upper width score, upper parabola score, rear parabola score, body length, thurl width and hip width were significant, and greatly affected $\mathrm{R}^{2}$-values in the equation for BCS estimation. Each regression coefficient for the three image analysis traits for BCS estimation was negative. Meanwhile, slight improvements in $\mathrm{R}^{2}$-values were found for meat luster and meat texture by including image analysis traits in the equations.

In Japan, the Tajima Wagyu is known as a high quality beef producer, but is rather poor in quantitative performance and shows an angular rump shape. Given this fact, fattening farmers believe that cattle with an angular rump shape might have good meat quality. Our results show that the relationship between BMS and parabola score is positive and is consistent with general opinion on the relation between beef quality and rump shape. However, the physiological relationships between them have not been investigated yet. There- fore, after pooling data, further analyses on various aspects should be undertaken to clarify the relationship between them.

BRETHOUR $^{1)}$ reported that the $\mathrm{B}$ mode ultrasound measurement method was effective for estimating marbling score : the correlation coefficient between ultrasound measurement and marbling score was 0.48 . FAULKNER et al. ${ }^{2}$ ) reported on significant regression coefficients between carcass traits and subcutaneous fat thickness measured by the ultrasound method : $\mathrm{R}^{2}$-values in equations for carcass fat, fat-free lean and bone percentage estimation, via live body measurements, were $0.85,0.59$ and 0.79 , respectively.

The accuracy of prediction for BMS and BCS on live bodies might be greatly improved by using the ultrasound and image analysis method simultaneously.

\section{Acknowledgments}

The authors thank Mr. Shigeru NisHiDA, Mr. 
Satoshi Ujne and Mr. Eisaku Suzukl at the Miyagi Prefectural Animal Husbandry Experimental Station for supplying progeny testing data. We wish to thank the Iwadeyama stock farm for assisting in video photographing.

\section{References}

1) BRETHOUR, J.R., Relationship of ultrasound speckle to marbling score in cattle. J. Anim. Sci., $68: 2603-2613.1990$.

2) Faulkner, D.B., D.F. Parkett, F.K. McKeith and L.L. BERGER, Prediction of fat cover and carcass composition from live and carcass measurements. J. Anim. Sci., 68 : 604-610. 1990.

3) HancoCK, L., M. KRIEGNeR, The C primer. 21-254 Ascii, Tokyo. 1984.

4) Holloway, J.W., J.W. Savell, P.L. Hamby, J.F. BAKER and J.R. STOUFFER, Relationships of empty-body composition and fat distribution to live animal and carcass measurement in Bos -Indicus and Bos-Taurus crossbred cows. J. Anim. Sci., 68 : 1818-1826. 1990.
5) KUCHIDA, K., K. YAMAKI, T. YAMAGISHI and Y. Mizuma, Predict of fat/lean ratio on beef loin using color image analysis system. Tohoku $\mathrm{J}$. of Jpn. Zootech. Sci., $38:$ 119-122. 1989.

6) Kuchida, K., K. Yamaki, T. Yamagishi and $Y$. Mizuma, Evaluation of meat quality in Japanese beef cattle by computer image analysis. Anim. Sci. and Technol., 63 : 121-128. 1992.

7) Murata, T., Factors affecting beef carcass price in relation to the beef carcass grading system. Jpn. J. Zootech. Sci., 59 : 269-277. 1988.

8) Nagamine, Y., T. Hayashl, H. Sato, A. Nishida and $\mathrm{S}$. Komatsu, The use of ultrasonic measurements on subcutaneous fat thickness in breeding of Japanese Shorthorn Cattle. Jpn. J. Zootech. Sci., 59 : 335-343. 1988.

9) SAS Institute Inc., SAS User's Guide : Statistics. 5ed., 1-.SAS Institute Inc. Cary, NC. 1985.

10) YAMAZAKI, $T$., The effect of age and fatness on the meat quality and quantity of beef cattle. IX Relationships between body measurements, carcass measurements, and tissue weights. Bull. Nat. Glass. Res. Inst., $43: 65-75.1990$.

\title{
黒毛和種去勢牛に抢けるコンピュー夕画像解析による 体測定值を用いた枝肉形質の推定
}

\author{
口田圭吾* · 山岸敏宏 - 武田尚人** 八巻邦次 \\ 東北大学農学部，仙台市青葉区 981 \\ **農業生物資源研究所，つくば市 305
}

\begin{abstract}
黑毛和種去勢牛に対する後ろおよび上方向からの画像が，ビデオカメラにより撮影され，コンピニー 夕のメモりーに取り入れられた．C言語によるプログラムにより生体の輪郭線が抽出された，上および 後方向からの牛生体画像の輪郭線の座標デー夕は，2次回帰分析により姏理された. 本研究では, そこで 得られた 2 次の項の回帰係数をそれぞれ上方向放物指数，後方向放物指数之定義した．同様に，画像上 の体幅之体長おょび体幅と体高の比をそれぞれ上方向広がり指数，後方向広がり指数と定義した． 12 形 質の体測定，13 形質の枝肉測定招よび超音波による皮下脂肪厚測定が，40 頭の黑毛和種間接検定材料牛 についてなされた，体測定形質抒よび画像解析により算出した放物指数ならびに広がり指数が，重回帰 による枝肉形質推定の中で用いられた，画像解析形質を取り入れることで $\mathrm{R}^{2}$ 值が大きく改善された形 質は，牛脂肪交雑基準および牛肉色基準であった，上および後方向放物指数は牛脂肪交雑基準に対して 正の方向に影響していた，同様に，上方向放物指数，上方向広がり指数书よび後方向放物指数は，牛肉 色基染に対して有意に影響して抢り，それらの偏回帰㐿数は負であった。また，肉の光沢捛ょびキメに 関しては若干の推定精度の改善が認められた。
\end{abstract}

日畜会報， 65 (5)：401-406，1994

現所属： * 仙台市衛生研究所，仙台市若林区983

日畜会報, 65 (5) : 401-406 